\title{
Chapter 9 \\ Global Residents in Urban Networks: \\ The Right to Asylum in European \\ Cosmopoleis
}

\author{
David Álvarez
}

\begin{abstract}
The purpose of this chapter is to examine the limitations of our current political structures in incorporating the cosmopolitan principles that may be emerging in the normative developments of our global order. The perspective that I take is explicitly cosmopolitan, although it is elaborated out of an exercise of immanent criticism from within our existing institutional order. This analysis confronts spaces of the incipient articulation of cosmopolitan realities with political models of international legitimacy. This scenario constitutes an example of the incapacity of national state democracies to give a proper account of their foreign duties through national or supranational institutions. We briefly examine two emerging political sites that partially realize cosmopolitan realities in defiance of the national system. The first case is the political space of our metropoleis and their distinctive disposition towards refugees in Europe. The second case is the emergence of a cross-border network of urban connectivity and the alternative characterization of the refugee flows as a constitutive part in this transnational social fabric.
\end{abstract}

\subsection{The Duty of Rescue: From Right, to Favor, to Interest}

We can interpret the right to asylum as a cosmopolitan norm on two counts. The first and perhaps most common reading is the one that stresses its individual character. Asylum is a legal status that is granted to an individual who happens to be in the exceptional circumstances where the collective political system where she is recognized as a member cannot or will not protect her basic rights. Therefore, as a vulnerable individual deprived of a protective political community, she depends on a subsidiary polity in which she could be incorporated. In this view, we tend to think of states as the primary political entities and asylum seekers as a secondary, derivative reality. They are similar to particles emitted from some otherwise stable

D. Álvarez $(\bowtie)$

Centre for Ethics, Politics and Society (CEPS), University of Minho, Braga, Portugal

e-mail: davidalvarez@uvigo.es; alvarez@ilch.uminho.pt 
compound. Only in these moments of crisis do humans reveal their vulnerability as unassociated elements, as members without membership. Cosmopolitanism is then portrayed as a residual circumstance that only emerges when the relevant political ties are severed. This view is sociologically and ontologically communitarian, and shared history and culture play a constitutive and normative role in it. It understands the duty of rescue paired with a duty to assist in restoring the conditions in the communities of origin so individuals can return where they really belong.

The second paradigm interprets the right to asylum in a cosmopolitan key because it presupposes that the individual has always been the fundamental unit of justification of any political association and that, in some ways, all political communities are tacitly still the product of a daily plebiscite. It is not necessary to subscribe a fictional image of a "natural man" before an ideal social contract or other radical atomist view. It is enough to assume that all processes of socialization should incorporate the necessary constraints that allow sufficient individualization amidst social life. Social conditions should nurture individuals. When these circumstances become oppressive for the necessary development of personal freedom and agency, they should provide avenues for reform. State recognition implies that other individuals, through their states, agree on respecting the authority of one territorial system because it provides their members with the adequate social conditions to exercise their agency. In return, their members reciprocally agree to respect other neighboring systems as legitimate forms of exclusion, as well.

Under this view, when a social order violates these constraints we can talk of state-collapse, and therefore, individuals find themselves without reasons to keep supporting a reciprocal system of jurisdictional recognition unless there is an operative safety net in place that assumes the responsibility of recreating those basic social guarantees elsewhere. If the international order does not live up to its own principles, then the legitimacy of its component parts is also undermined. Taken to an extreme, this view would even defend that the coercive and exclusionary force that polices national borders would also lose its authority; that is, they could not claim fully justified grounds to command and demand voluntary compliance. In that situation, from a cosmopolitan view, the outsider is right to consider the other side of the line as a neighboring society and not as a foreign state (Álvarez 2012).

According to the first interpretation, the conception of cosmopolitanism implicit in the right of asylum is of an ethical-humanitarian type, as its normative source springs from the collective duty of rescue towards an individual in circumstances of vulnerability. It is an ethical patch for the political punctures in an otherwise decent system of sovereign states. The second reading, in contrast, is political at its core and rests on a fundamental cosmopolitan legitimation of the international system.

These two readings also tend to entice two correlative reactions on the part of the rest of the international community. This duality is also captured by the distinction between asylum seeker and refugee. As Didier Fassin (2016) crudely remarks, asylum is a condition that occurs in the West, while refugees belong in the global South. Asylum is a status conferred to those who are seen as worthy of solidarity among Western liberals and who deserve to be treated as one of us. Refugees, in contrast, are masses of people subject to pity or compassion, who should be assisted and 
contained in remote locations where their basic needs can be sufficiently satisfied and their claims on our humanitarian duty cancelled.

Fassin also documents a shift in the interpretation of the asylum doctrine, from right to favor. This move follows a world in which conflicts become more tightly intertwined, and more civilians are affected for longer periods. In contrast, the international structures to address our shared responsibilities have not kept pace.

The political consequence of this gap is that what was first considered as a robust right that was almost routinely granted is now a matter of discretionary policies, surrounded with suspicion, ferociously guarded, reluctantly conceded, and politically magnified.

In response to what they call a broken refugee system and in the face of the challenges ahead, Alexander Betts and Paul Collier advance a pragmatic proposal of reform (2017). In their diagnosis, they identify a priority: the refugees that are most in need are those that remain close to the conflict. Rich countries have a strong preference for keeping them there. However, host countries may have a strategic interest in taking advantage of the situation for self-serving interests that donor countries would not want to support. For instance, host countries could use the funding not only to back their own authoritarian regimes but also to invest in sectors that threaten interests in donor countries. For these reasons, the authors affirm that the normative aims implied in the right of asylum cannot be met within the current order of sovereign states. The only reasonable alternative to advance towards those moral goals is to reform the system in a way that aligns the needs of the refugees with the national interest of the states involved. The particular proposal that they advance to harmonize all competing interests is to create special economic zones next to resettlement areas, where subsidized foreign firms would employ local and refugee labor. This way, donors push their firms, host countries attract foreign direct investment, and refugees get economic self-sufficiency. From right, to favor, to interest.

Without discussing in detail the problems in this polemic proposal, we will only briefly comment on the reasons the authors give to favor resettlement in proximity. The main arguments are class and culture. Regarding class, they defend that most of the refugees cannot pay the fees to reach richer countries, and once there, they would lack the adequate skills for successful social integration. When we talk about the refugee crisis, they are the $99 \%$. In contrast, only a small $1 \%$ constitutes the educated elite who can aspire to resume their lives in more advanced economies, but they are not the most vulnerable group. Regarding the cultural argument, the authors defend that neighboring countries usually share cultural values, common history, and similar languages. Therefore, socialization and employment would be easier for the most vulnerable population.

These are plausible reasons. Conceding that Betts and Collier may be right about the empirical conditions, I would question nevertheless some reasons in their proposal that I find problematic. In the first place, by resorting to national interest to meet the international duty of rescue, Betts and Collier help perpetuate the very same problem that they correctly diagnose. We have an international order that is incapable of regulating the conditions of an increasingly interdependent world and that cannot address these consequences based on shared remedial duties. The 
advisable path that the authors offer is to lower the normative bar so that it can converge with a system of national interests that now seems incapable of abiding by its own standards of legitimacy.

In this case, the solution implies deferring to the donor country interests' to keep the refugees at bay because otherwise, their generous social conditions would trigger a call effect for a vast unemployable population that would generate a chain of onerous social demands that could be used by national populist movements to create xenophobic reactions and political instability. Betts and Collier cite Brexit and border chaos in Europe as a consequence of Merkel's inability to match ethical calls and political realities. Again, without going into much detail in a single example, it is worth recalling that many of these unintended consequences are in fact baseless perceptions magnified in a public pathos of panic and alarmism.

Even if it is true that Merkel's "call effect" appealed to many refugees who were safe in camps to become economic migrants, it is also true that this distinction is becoming particularly blurry if we consider that the standards for sufficient human rights protection were not intended to be applied to long-term situations of life on hold with dim prospects of improvement. Arjun Appaduray (2004) defined the poor as those that have no capacity to aspire. This means that "having nothing to lose" is not enough to motivate initiatives when one cannot even conceive of opportunities and possibilities ahead. Those who risk their lives are not absolutely desperate. In this sense, the authors are right to stress that the European crisis distracted public opinion form the real drama of those refugees who were left behind in remote safe havens and who cannot even aspire to restart their lives elsewhere. Those who made it to Europe had some kind of capital that backed their hopes, be that economic (for the trip), human (skills), or social (networks of support and contacts). Those refugees had aspirations for a decent life above mere stagnation in safety. Even the surgically analytic philosopher David Miller acknowledged that the refugee crisis exceeded the clear-cut categories of his philosophy of immigration and that it deserved an explicit epilogue (Miller 2016: 167-168).

Miller's main worries are now whether a wider asylum policy would incentivize brain drain and push back the prospect of reconstructing refugees' homes in Syria and whether a shared-burden system of quotas in Europe is compatible with the European open border policy (Miller 2016). Miller's analysis is consistent with his defense of national determination over cosmopolitanism. On the one hand, he implicitly conceives those with the opportunity to migrate as some sort of national capital. They constitute, as a whole, the human capital of the poorest refugees, even if kept in camps as some sort of human savings. Correlatively, Miller defends a qualified right to close borders to migrants because this transborder flow would undermine the goals of a burden-sharing system of national transfers and compensatory financial aid. This consideration follows a national bureaucratic logic that represents refugees as proportional national quotas instead of per-capita budget allocations that should ideally follow the refugee through her personal journey. It is not clear whether Miller's position on this bureaucratic problem reflects a nationalist bias in favor of compensating some domestic social fabric for the hosting effort or merely accepts the incapacity of the institutions to fully tailor the individual funding needs of border-crossing agents. 
In the case of brain drain, there are reasons to think that many refugees would prefer to return when safe and possible or that remittances back home would compensate for the opportunity cost of frozen human capital. There are also very good reasons to think that our moral priority lies with those left behind and with minimizing the need to leave. The problem, however, is that the needs of refugees had not been an international concern until some of them reached Europe, in part because local reactions openly challenged national interest. However, the problem of the pragmatic approach of aligning duties with national interest is that such a strategy reinforces the nationalist drive, while it downgrades the critical horizon for its normative assessment. As a consequence, this move prevents the emergence of the new institutions necessary for coordinating political action in the face of complex and interdependent global threats.

In the following sections, we use the broken refugee system as a case to test the limits of two prominent conceptions of the legitimacy of the international system. Thomas Christiano (2010) defends a model based on state consent to realize a set of morally mandatory international goals. In his view, state consent protects the intrinsic value of public equality in democratic decision making (Christiano 2008), while democracy is also instrumentally justified for promoting global standards of legitimacy such as human rights (2011). Alternatively, Cristina Lafont (2012) reacts to the trend to trim down the list of human rights into a core list of state-centered urgent concerns by defending a maximalist conception of human rights embedded in the global institutional order (2012). Our analysis shows that neither of these theoretical frameworks overcomes the problems of national interest and domestic bias regarding foreign duties. This temporary conclusion leads to the final part of this essay, in which we explore the contribution of European global cities in incorporating a cosmopolitan dimension into the global order.

\subsection{The Legitimacy of the International Order}

\subsubsection{State Consent and Global Institutions}

Thomas Christiano's model of democratic authority is a conception for the realization of the intrinsic value of public equality in the purchase of political goals and the reproduction of a common social world among those who share equal stakes in their subjection to a common political authority (Christiano 2008). It is compatible with an instrumental justification of democratic authority based on its efficient determination and the realization of the goals of political life at a domestic level and of a set of morally mandatory goals at the international level (Christiano 2010, 2017).

Connecting those levels, Thomas Christiano defends an institutional architecture for the international order that derives its political legitimacy from the consent of its state members. According to this proposal, there are some fundamental principles and institutions that have some proto-constitutional authority and binding force over all states. These institutions regulate the most urgent matters for a peaceful 
coexistence. Beyond this layer, there is an intermediate level of functional institutions for international cooperation. Their constitution, however, needs only to reflect the voluntary agreement of the parties through a process of fair bargaining. Such a process of institutional design should express the different contributions of states, the functional complementarities of their interests, and a special status conferred to the less developed populations.

The strong point in Christiano's conception is that it is intuitively appealing as an idealized model of our international system, which gives it a credible regulative force. The idea of a transfer of legitimacy through legitimate consenting parties also seems to be a plausible model for institutional incorporation. Unfortunately, this model only works if we presuppose that the parties designing the institutions through consent are able to establish democratic deliberations among citizens that conceive themselves as members of a global order. However, this requirement seems difficult to reconcile with our experience of the strong domestic bias in democratic deliberations, which seems to be a structural feature of modern democracies. The challenge for Christiano's conception is to provide efficient accountability regarding the claims of outsiders while keeping the intrinsic value of democratic authority (Álvarez 2017; Christiano 2017).

The problem is that the institutions of public equality represent the common social world of those who share equal stakes in its daily reproduction. The institutional continuity of this political community as a stable state is intimately linked to the efficiency of such an organization in representing strong membership bonds and shared commitments among those included as citizens. Simultaneously, the strength of the representation of national co-responsibility overshadows the severity of foreign claims and the relevance of external commitments, even if they were once endorsed through the authority of state official consent. This is, for instance, the case of the Refugee Convention analyzed by Joseph Carens (2013: 215-224). In Carens's view, the problem of resettlement allocation is not one of intellectual disagreement about fairness but merely one of lack of political will, which cannot be solved easily by a rearrangement of self-interested incentives because "the gap between what morality requires and what serves even long run self-interest is so great that interests can do very little to support morality" (Carens 2013: 223).

If we translate this situation into Raz's conception of authority as service (Raz 1988: 56), we can conclude that modern democracies suffer from systematic partial legitimacy because the system generates perverse and interlocking incentives among public authorities and citizens alike to misinterpret the reasons that apply to them as members of a collective member of the international system. By following biased directives related to foreign responsibilities, citizens contribute to a substantial misallocation of resources, to the habitual undermining of global institutions and to the consolidation of an overgrown conception of national interest. This is not merely a case of alienation from domestic authority because of lack of identification with the laws promulgated. For instance, in Raz's own example, this would just mean the inability to self-identify with the "we" in the sentence "we just changed the law to make it more difficult for asylum seekers to stay in the country" (Raz 2010: 163). However, the case we are examining does not focus on isolated domestic 
laws but on the systematic disrespect of domestic authorities for official and binding commitments that are recognized as standards of international legitimacy.

Therefore, those citizens that are aware of this systematic unbalance of competing claims for resources in democratic deliberation may feel trapped in a political system that systematically neglects or sabotages the very same standards of legitimacy that it endorses.

One possible alternative is to introduce within the domestic political system corrective mechanisms such as courts and constitutional dispositions that counter the domestic bias in democratic deliberation. By doing so, standards that were once legitimized through the intrinsic value of democratic authority and affirmed through state consent are now transformed into external standards of epistemic correctness that are applied to validate the outcomes of democratic deliberation. This means that democratic authority is being evaluated according to its external performance in an instrumental way. When we confront democracies with their systematic underperformance regarding severe foreign commitments, we face a dilemma: either we defend the intrinsic value of democratic authority and condone its systematic disregard of its own standards of legitimacy, or we defend institutional reforms in political deliberation in instrumental terms, according to their capacity to satisfy external standards.

In contrast, the introduction of instrumental corrections in domestic institutions would tend to limit the intrinsic value of collective self-determination as the realization of political equality. Even if these goals and measures had been domestically ratified, individuals would feel that they had no effective control of the institutional process that leads to their implementation. This second option presupposes that political institutions are integrated in a process conducive to the achievement of evident and mandatory moral and political goals. Following this line, democracies can be justified as the most legitimate political system because they are the most effective regime in building the kind of political stability and collective support for the achievement of these common and mandatory goals. For instance, we may say that the European Union with its hybrid democratic-functionalist logic is an imperfect but close implementation of such a model. Its foundational inspiration rests on the perception of the intrinsic blind spots of national interest that may lead to perennial conflicts and the inability of the demoi to perceive the self-interested advantages of a democratic peace among trading societies and commercial nations. Therefore, the functionalist logic builds on the institutional inertia that progressively shapes the social environment in which democratic decisions are presented. This scenario may be correctly perceived as a democratic deficit form a perspective of the intrinsic value of popular sovereignty. However, simultaneously, it can also be defended that the model does not only guarantee the convergence around common goals of shared prosperity. It also prevents the anti-democratic decisions of a people that, for instance, could violate the legitimate interests of other peoples or minorities.

An alternative could consist in making explicit the non-national elements within the demos, for instance by amplifying the political input of megacities, as political spaces where coexistence is marked by a distinctive ethos of common residence among nationals and foreigners alike. We will explore this alternative later. 


\subsubsection{Human Rights and Global Institutions}

As we argued, when seeking to align international duties of asylum with national interests, one of the tempting strategies is to downplay these global demands because political representatives will not be held accountable for these duties towards foreigners by their national constituencies. As a consequence, we find that we have a growing and sophisticated international legal regime that develops independently of an also expanding number of philosophically ambitious conceptions of human rights but that neither of these norms or doctrines have a substantive effect in shaping the practice of states. In contrast, the proliferation of moral constraints, goals and shared responsibilities in the international community and international organizations had the predictable consequence of devaluing the force of these global normative tools.

Facing this precarious state of the art and partially inspired by Rawls's (1999) approach to what is a realistic utopia for the international order, Charles Beitz (2009) proposes a practice-dependent understanding of international human rights that is political in its nature and functional concerning its content. This means that this political conception understands human rights as a normative practice of claimsmaking similar to the one that occurs between courts, lawyers, bureaucrats and activists. Additionally, by shifting the focus to the conditions for respecting sovereignty among states, this political account does not need to be grounded on a unifying metaphysical doctrine or a philosophical anthropology. It implies that the content of human rights in practice should be limited to matters of urgent concern that justify the intervention of foreign states. Although this concern does not need to be restricted to military interventions, the focus on urgency serves also to justify a clearing house approach against other inflationary lists of rights.

This approach could illuminate the schizophrenic state of mind that seems to haunt liberal democracies. In the words of Matthey Gibney (2016), it seems difficult to otherwise understand how the duty of asylum is at the same time so central to the liberal values and so systematically undermined in practice. Such an inconsistency leads us to question whether asylum is actually not the norm but a discretionary exception. In addition, if we are right, what calls for explanation is its formal normative subsistence among liberal democratic peoples. Therefore, can asylum still count as a human right when states seem so unlikely to act on it? What is a right and what is a favor when we exchange claims about asylum?

Although Beitz does not explicitly discuss the topic, the problem of the definition of the scope of the statute of refugee is a case in point. Proposals vary from the more restrictive readings of the Geneva Convention that limit the application to victims of persecution, to more expansive interpretations that also include those affected by civil war and other conflicts, natural catastrophes, climate or extreme poverty and unsustainable social conditions. Some would focus on the type of risk, such as when Betts (2015) extends the status to all those under an existential threat in their state of origin and forced to flee for their lives as "survival migrants." Others, as Blake (2016) remarks, also consider those who can still make a compelling case to flee for better lives. Related discussions can be opened about the rights granted to 
refugees by the host country: should they have a right to work, to trade, to relocate, to citizenship?

In this discussion, the political conception defended by Beitz would aim to delineate the strictly uncontroversial core of a state's duty of rescue. That is, the clear conditions in which a state's failure to rescue would justify external interference or even sanctions. In contrast to this state-centered and minimalistic approach, Cristina Lafont (2012) develops an alternative political conception that avoids narrowing the scope of international rights protections by giving normative prominence to the agential capacities of the international organizations of the global order.

In Lafont's account, a more extensive list of socio-economic rights should be embedded into the official mandate of the institutions of the international order. The justification for this maximalist interpretation of the political conception is that the institutions of the global order play a substantive role in the ability of sovereign states to realize the human rights of their populations. However, it is not always clear how we should interpret this human rights mandate, whether as respecting the capacity of states to realize these goals by avoiding obstructing policies and interferences; as protecting vulnerable populations through intervention when these interests are threatened by their own state or third parties; or as directly assuming responsibility for the implementation of these goals. This is no minor issue for a political conception of human rights since its defining characteristic is the identification of functional criteria for the attribution of subsidiary responsibilities.

Lafont's conception of human rights represents an interesting counterpoint to the more minimalistic and state-centered views. It is embedded in the overall system of international coordination or cooperation and not merely in the official institutions of human rights. Lafont's argumentative strategy is very persuasive because it works within the political conception by redirecting its own state-centered arguments into a more cosmopolitan outcome. For instance, if you care about the role that the costs of external responsibilities play in defining what really counts as a matter of urgent international concern (Beitz 2009), then shortening the list of common concerns and raising the trigger level represent a flawed approach. This functional interpretation of human rights fails to take into account the equivalence between security and subsistence needs and the role that global institutions may play in enabling domestic socio-economic performance and minimizing exceptional needs of intervention (Lafont 2012). In our case, this supports extending full asylum rights to economic refugees as well, including the right to work, relocation, social welfare, and the path to citizenship.

Additionally, if you are concerned about the imperialist abuse of human rights rhetoric to undermine the value of sovereign independence, then you may also focus on the role that a strong global order may play in supporting and restoring sovereignty against foreign agents and systemic factors (Lafont 2015, 2016). In our case, this could support the case for a fairly enforceable global refugee quota system, global duties for post-conflict reconstruction, facilitating conditions for a right to return, and even a compensation system for brain drain.

The problem with Lafont's approach is that it does not really take into account how political is such a political turn. We can say that this new direction is political 
because it aims towards a non-comprehensive framework. However, we can also say that it is so because it assumes the intrinsic limitation of a system of states. This means that even if an argumentation seems compelling in a deliberative framework for a non-comprehensive agreement, it does not necessarily translate into the kind of reasons that may trigger in domestic institutional settings the adequate response of co-responsibility towards outsiders. By shifting the burden of co-responsibility and collective coordination to the global order, Lafont also needs to show how these same states are able to tame this same domestic bias in the negotiations about global institutional design.

The success of this strategy depends on two factors that currently limit the performance of international institutions' efforts to enhance the legitimacy of the global order. On the one hand, the internal legitimacy of these institutions is based ultimately on state consent, and as mentioned previously, the principles of their constitutive mandate tend to reflect a balance of national interests. They therefore have an original flaw in their design. On the other hand, even when they officially recognize relevant responsibilities that reflect the fundamental standards of the legitimacy of the global order, they rarely have the effective capacity to pool the necessary means to implement these officially acknowledged duties. State members tend to systematically underfund these institutions or fail to mobilize the required resources unless they have a converging interest. Even if state parties confer formal legitimation to the institutional goals through their explicit consent, they can always rely on the domestic implicit consent from their constituencies to maintain this pattern of selective underperformance. In fact, domestic accountability is generally biased against any sacrifice of national interest in favor of foreign parties. The most telling example is perhaps the failure of the European Union to overcome the different national interests in order to implement a mandatory quota system for the distribution of the refugees already in its territory.

Unfortunately, the political turn in human rights does not offer the detailed account of a non-statist conception of political practice that a global turn would require. In Beitz's case, this practice is limited to an elite cluster of activists, state officials and international bureaucrats. For Lafont's account to be convincing, it must provide a complementary account of civic-cosmopolitan political agency to counter the dominant view of national interest. In the following part, we explore the role of global cities as emerging political subjects with the capacity to influence deliberations in a cosmopolitan way.

\subsection{Cosmopolitan Cities}

\subsubsection{Cityness and Civic Ethos}

This exploratory interest in the political landscape of European cities is justified on two counts: first, as political entities, cities may represent conceptualizations of political problems that differ from the national aggregate; second, urban networks 
also constitute flows of exchange that transcend the national framework and realize a localized experience of the European project. Therefore, cities are cosmopolitan realities that provide a contrasting anchor point for political reflection. The expression of such a distinctiveness occasionally makes explicit a direct confrontation with national political lines, leading to policies of strict non-cooperation that are similar to the refusal of sanctuary cities to collaborate in the identification of illegal immigrants; the explicit development of cities of refuge of a policy of accommodation of refugees; or the direct implementation of environmental policies or emission cuts in line with global policies that the national authority openly neglects or attacks. This exploratory proposal does not vindicate the role of cities as a sort of political silver bullet for global problems. To be clear, cities can equally be bastions of extreme localism or uncompromising not-in-my-backyard policies. The approach that guides this exploration is neutral about the content of city politics and more focused on its structural capacity to become alternative agoras to the national aggregation of political interest. Consequently, it does not advocate any utopian vision of city politics. In contrast, it argues that the political contribution of urbanity rests in its condition of localized topos. However, to assess this potential, we first need to understand what makes cities distinctive in our global order and how we can give adequate expression to their political voice.

Urban settlements shape a distinctive kind of political identity in contrast to the national one because it makes explicit the degree to which national commonalities are imagined. National identities are generated and reproduced through processes of abstraction and socialization through common curricula, media exposure, etc. Foreigners are also represented through correlative mechanisms of abstraction and stereotypification. Local conflicts, in contrast, are opportunities for testing general assumptions about the other in settings where particularities carry a heavier weight than generalities. Although national identities are being enacted and reclaimed at the local level all over the country, in many cases, the conceptualization in which the conflict has been framed would contrast with diverging first-hand experiences, exposing mobilized individuals to cognitive dissonances. That would be, for instance, the experience of many refugees fleeing from cities torn by civil wars that polarized conflicts among neighbors to previously inconceivable levels. From Sarajevo to Aleppo, recent memory is full of harmonious mixed populations that become existential antagonists when national identities are activated. The argument in favor of megalopoleis argues precisely against this artificial homogenization of political space. The national imaginary has been instrumental for extending local loyalties and solidarities beyond the near and dear. It has worked as a political ideology that carried some degree of universalization through the extension of the status of local membership to equal co-nationality. The national cause was also in part the result of the preeminence of the landed aristocracy and the rural world over the cities. Today's Europe attests to the contrary, as an example of urban exodus and urbanization of the countryside; however, political representation is generally dominated by the image of the territorial nation and the expectative of preferential solidarity across the land. Electoral representation tends to mimic this image in the distribution of political weight through national districts in a way that balances the 
demographic hyperdensity of the cities by over-representing unpopulated country districts. Even when subnational divisions exist, the abstract modern ideal of political equality is territorially adjusted to represent a homogeneous space of national sovereignty, an abstract territorial jurisdiction for an imagined community. Consequently, nationality takes priority over citizenship as a political identity, which translates into the economic and institutional way of integrating the territory. The alternative does not consist in substituting national allegiances for local ones. In contrast, the proposed alternative consists in avoiding political simplification by emphasizing spaces where political life is constituted in a different way. For instance, Thomas Christiano's conception of political equality presupposes that the scope of the political community should enclose those who share equal stakes in the reproduction of a common social world. It is taken for granted that this level of coresponsibility corresponds to the territorial state, which may have a more or less centralized structure or be articulated in subnational units. Our working hypothesis, however, is that metropolitan politics constitutes a qualitative discontinuity in the political landscape that is not reducible to other federal articulations of political representation. For instance, the distinctive conditions of hyperdiversity and hyperdensity require a different set of political virtues, dispositions and capabilities. They are fit for living in megalopoleis, which are lands of strangers that would not meet the communitarian expectation of more traditionalist communities (Amin 2012; Amin and Thrift 2017). This concrete experience of coping with diversity does not always translate in a differentiated political influence in a world of states.

Paradoxically, despite their lack of cosmopolitan input, global cities have also become global sites that challenge the capabilities of modern states to plan and control transborder flows. Globalization, according to Sassen (2006), consists in a new articulation of territory, authority, and rights. Its most characteristic manifestation is the denationalization of the economy, which takes eminent place in cities. Some cities emerge as crucial hubs with the capacity to command and control the flows in vast and dense transnational networks. Other authors, such as Neil Brenner (2013), downplay this capacity, arguing that city centers operate merely as switch mechanisms, opening and shutting flows in the network but lacking further decision power about the content of the programs. While Sassen's work is a pioneer in the study of the liminal zone in which the city extends its colonizing capacity over nonurban areas, Brenner's analysis tends to resist the spatial identification of the urban society with the geographical unit of the city. For Brenner, the city is indissociable from modern capitalism, which is a social organization that has reached a planetary scale. Therefore, for Brenner, the urban condition, to different degrees, is the dominant way of life (Brenner and Schmid 2015). The two approaches share a good deal of common ground, differing in matters of degree and emphasis.

Sassen (2014), for instance, also recognizes the severe and disruptive effects that urban growth imposes on peripheral regions that are depleted as mere suppliers of resources and infrastructures of communication. Brenner puts the emphasis on the transformations that hyperconnectivity imposes on the sites colonized by the material and logistic demands of global capitalism and insists on this prism as the privileged lenses to understand the global urban condition (Brenner 2013; Brenner and 
Schmid 2015). Sassen's analysis, although it depicts global cities as centers of power, also insists on how the transnational and privatizing dynamics of global capitalism are creating zones of exclusion and marginalization in our cities while depriving residents of real power to shape their lives. In a metaphorical way, for Sassen, cities have a voice (2013). They can talk as integrated networks of infrastructure and population through their break-outs, collapses, and failures. She suggests reading these events as acts of resistance that point to planning defects. Sometimes, these issues are voiced by segments of the population as explicit political claims. Other times, they are expressed through the pragmatics of dysfunctional repurposing or temporary adaptations of urban resources to different uses. Housing, accommodation and integration are urban demands that put existing infrastructure to a pressing test. They also require creative dispositions on the part of new and old neighbors. Sassen calls "cityness" the capacity of urban spaces to "talk back" as an open system for interaction, enabling, for instance, the creation of public spaces according to need and independently of preconceived planning ideals. Cityness as a concept aims to capture an urban virtue of the built environment that is different from the heavy Western connotations of "urbanity." In turn, cityness aims to broaden the view to all those realizations of public spatialization that are neglected by our cultural expectation of the Western ideal of the city. In this sense, by incorporating a receptive disposition to other ways to interact with different forms of the city, cityness opens up a truly cosmopolitan view (Sassen 2005).

Urban politics differs from other levels of articulation of political discussion because it tends to be more immediately constrained by pragmatic and infrastructural demands. Unlike abstract constitutional debates about doctrinal interpretation, urban politics demands a spatial determination of the political. Although ideas and beliefs do play a role in city politics, conflicts are also activated and deactivated at more pragmatic levels. Therefore, in city life, individuals are taken in their full agential dimension and not reduced to just believers or supporters.

This spatial imperative does not need to be interpreted as a strong structural determination, although that was the underlining radical assumption in Henri Lefebvre's seminal formulation of a right to the city. For Lefebvre, this ideal was in line with claiming direct participation in the management and production of urban space, which is a way to frame human emancipation as an urban revolution in the age of planetary urbanization (Lefebvre 2003, 2012; Purcell 2013). Following the path opened by Lefebvre's radical conception of the right to the city, other authors (Harvey, Brenner, Soja, Purcell) adopted this formulation for political analyses that include the spatial conditions of human habitat without giving it the strong causal determination that it has in Lefebvre's work. In general, they tend to differentiate Lefebvre's use of the right to the city from the more common dilution of the term by social movements, coalitions and charters as rights in the city. For instance, David Harvey (2013: 25) incorporates the geographical description of the reproduction of spatial injustice under capitalism and the right to the city as a limited political tool of resistance to mitigate its effects. In a similar way, Neil Brenner advises against the potentially adverse effects when demands about local rights to "quality of life" 
for some constituencies imply costs for other populations of a planetary urbanization (Brenner 2013: 176-7).

In relation to the political agency of city users, Edward Soja (2010) follows the demands of urban collectives and conceptualizes new categories of spatial injustice by interpreting the constitutional principle of non-discrimination in a way that justifies a criterion of compensatory priority in urban planning (Soja 2010: xiv-xvi). Susan Fainstein (2010) follows a more normative direction, arguing that even if urban politics is strongly contextual, urban planners can develop sufficient basis for judgment for a conception of the just city that combines equity in access, participatory democracy, and residential diversity.

In a partly similar way, Leonie Sandercock (2003) develops an ideal of cosmopolis that adopts the language of the right to the city for problems of integration in post-colonial metropoleis. Her project combines normative, symbolic and emotional analyses in the study of the resistance of hyper-diverse communities to integration. It starts by questioning the arguments behind strict demands of integration directed to populations coming from former colonial territories or to native indigenous peoples expelled by metropolitan settlers. Consequently, she defends a normative model of urban citizenship that recreates the claims of the right to the city through the specific lenses of cultural difference at the level of everyday experience of the built environment to promote a subjective sense of belonging (Sandercock 2003: 150-151). This goal is facilitated by a duty of accommodation that should be considered part of the imperial legacy of metropolitan powers. Under this light, urban policy should not only consider the rational arguments of the right to the city but also anticipate emotional reactions of fear, distrust and rejection and plan in advance public spaces to counter such effects. These spaces are part of the commons around which public discussion and disagreement should be expected to emerge. It is important to remember that even if the commons are a focal point for reconstructing urban life, civic participation should not be interpreted in a communitarian key. For instance, Ash Amin (2012) denounces the regressive effects of the recent recommendation of politics of care, social cohesion and a civic ethos of reconciliation in urban planning (Amin 2012: 33-34). Amin warns against this misguided reliance on amplified affections that are not accompanied by the adequate institutions for workplace collaboration, shared innovative learning, and engagement with the commons. One of the side effects of the direct emphasis on overcoming differences through a communitarian approach to inclusion and social ties is that the marks of unassimilated strangers tend to mutate and persist through shared institutions under a communitarian language that masks xenophobic and discriminatory outcomes. Therefore, realistic urban politics should be based on respectful distance, principled disagreement, and common life (Amin 2012: 3-7).

This quasi-agonistic spirit is ubiquitous in the direct character in which local conflicts are depicted, in part also as a vindication of civic vitality - for instance, in Sennett's pioneering The uses of diversity (1970). However, it would be equivocal to assimilate the conflictual element at the base of the regulation of hyperdiversity with a defense of a politics of agonist hegemony. At this point, our exploration of cosmopolitan cities reaches a substantial problem. So far, the chapter has defended 
that giving stronger political influence to cities could have a countervailing effect against national interest for the realization of the shared duties of rescue and asylum in the global order. This was suggested because cities tend to generate a distinctive cosmopolitan ethos. However, how could we politically articulate this distinctive voice of agonistic hyperdiversity?

\subsection{The Scale of Agonistic Populism}

The particularity of urban politics is generated by the specific constraints of its agonistic space. These are traditionally limited to an ethos of coexistence and cooperation, but to promote the role of cities as political subjects, we need a political language capable to articulate these agonistic demands as a political force beyond the local level.

This chapter argues that, despite its merits, the conception of hegemonic populism and agonistic pluralism developed by Ernesto Laclau and Chantal Mouffe cannot play this function for the articulation of a countervailing cosmopolitan influence. The reason is that this agonistic populism relies on the articulation of demands in a symbolic language that cannot integrate both the distinctiveness of the different urban agoras and an overarching symbolic articulation.

Hegemonic politics has a problem of scale. It cannot keep the motivating force of its rhetorical articulation of demands in the same symbolic key at the local and supralocal levels. If it succeeded, it would duplicate the hegemonic symbolic construction of the national as an imagined community and, therefore, the familiar problems of national interests. If it failed, it would accentuate the antagonistic struggle among local hegemonic identities (Papanastasiou 2017). The populist project is, after all, a political task of constructing a singular people through the demarcation of an antagonistic social fracture. This people is a singular political subject constructed through the articulation of heterogeneous social demands through a chain of equivalences into a hegemonic symbolic construction. This incremental dynamic of incorporation of new demands is a process of breaking and making. The emergence of the new hegemonic formation presupposes the breaking with the previous symbolic order and the replacing of its former articulating reference. Hence, even if social heterogeneity is a precondition for the construction of a people, this constructive process is one of symbolic unification. Therefore, it cannot allow for the subsistence of rival symbolic orders within the people that do not converge with the hegemonic order. Under these conditions, the distinctiveness of every city would be eventually subsumed under a larger symbolic identity. This is why populism has a problem of scale. There is no guarantee that a symbolic order that is receptive to the agonistic politics of local residence could be incorporated in a hegemonic discourse of peoplehood without suppressing the critical edge of agonistic local residence. However, it is the distinctiveness of this local dimension that we want to preserve and promote as a counter-hegemonic power against the driving dynamics of national interest. 
For instance, (Chantal Mouffe 2017; Mouffe and Miesse 2012) advocates the concrete urban conditions as privileged scenarios for the materialization of nonrational forms of communication through artistic interventions in the public space. The purpose of these new symbolic expressions is to subvert the semiotics of the dominant order by making explicit a political fracture around which to create a new hegemonic force. However, if this intervention were effective in capturing the specificity of local demands, then it would lack the potential for context transcending mobilization. On the other hand, if this symbolic intervention resonates with hegemonic force beyond the city walls, it is probably because the local agora has been colonized and assimilated as a subsidiary stage for a larger popular subject.

In a similar example, Laclau (2005) illustrates the assemblage of chains of equivalence of social demands with the case of newcomers, immigrants and potentially refugees to the city's outskirts and their progressive claims for housing conditions that resonate with related demands for public services and infrastructures of other neighbors (Laclau 2005: 72-74). In practice, however, most of these movements that frame their demands in the language of the right to the city fail to merge into a unified political subject. In contrast, their strength rests in their local specificity, and they tend to organize in pragmatic coalitions and alliances. They resist the dilution of their political capital into a new people (Nicholls 2008; Purcell 2009). Even if they organize into larger scales, connecting local struggles with networks of solidarity in global justice, their strength remains local, in what Soja (2010: 154-155) calls "community-based regionalism."

For this reason, Mouffe's endorsement and adoption of Massimo Cacciari's proposal for a multilevel organization of the European Union with multiple sites for alternative allegiances resembles a landscape after a lost populist battle more than a truly populist project for Europe (Mouffe 2013: 50-54). In agonist-populist terms, conflicts through different political scales are temporary struggles for symbolic integration of demands into larger chains of equivalence. The agonist-populist project is better characterized as a theoretical account of hegemonic political mobilization than as an institutional blueprint for a social order. Populism is a movement that is defined by shifting borders in an intrinsically antagonistic dynamic. Therefore, it cannot prescribe what particular constellation of multilevel resisting sites of allegiance and symbolic identification articulates the most inclusive emancipatory potential for a demos that is also accountable for its global co-responsibility towards outsiders. Advancing such a proposal would amount to taking this balance of counter-hegemonic sites as fixed positions. Democratic populism provides the conceptual tools to subvert a hegemonic order, but it lacks the theoretical resources to defend a positive project of institutional design.

Mouffe's project of antagonistic agonism claims to be explicitly receptive to the question of scale and mode in her affirmation that there is no privileged space for the political (Mouffe and Miesse 2012: 25-26) and in her support of a conception of global multipolarity (2013: 19-42). However, there are two main constraints for local agoras that are especially relevant for the incorporation of refugee-related demands into the political agenda and that seem problematic for the populist articulation. 
First, the condition of hyperdensity translates into a situation of unavoidable interaction in urban politics. Acknowledging this constraint requires an extra caution against the inflammatory potential of the antagonistic dynamic of populism, with special consideration to the vulnerable situation of minorities and new residents. Agonistic democrats are aware that galvanizing struggles into a common cause would always imply exclusions that may converge around minority scapegoats, framings of fifth-columnism, and other strategies of xenophobic populism. This risk is especially serious when direct interaction is mediated by a construction of the other that neglects the inconvenient particularities that do not fit with its functional role as antagonistic other and when the potential for violent action is real.

Second, the condition of hyperdiversity implies the paradoxical fact that the common ground for the institutions that sustain the basic principles of the ethicopolitical space, in which antagonistic agonism can occur without degenerating into violent confrontations, is thinner at the local than at the national levels.

Mouffe admits that creating union would depend on forging some thin conflictual consensus, consisting merely in the acknowledgment that "we are working together towards a common aim" (Mouffe and Miesse 2012: 18). In Mouffe's terms, the legitimacy of a dissociative agonism that depends on locating cohesive fractures that isolate political opponents rests on the wider inclusivity of an associative agonism that legitimates the basic institutions of the common space (Mouffe and Miesse 2012: 24).

However, it is in the local agora where we experience the encounter with the stranger. Appropriate interaction at this scale demands a set of virtues and dispositions that are recreated literally at every corner (toleration, charitable interpretation, civility, translation, accommodation, etc.). This set of urban virtues is instrumental for the maintenance of the more general principles that legitimate the institutions of agonism. However, because the local is also the context of the community of strangers, the ethico-political principles shared by the community of residents may be thinner than the imagined construction of the national community of citizens. In the language of populist agonism, this means that the "empty signifiers" for the symbolic aggregation at the local level may be emptier and thinner than at the national level of abstraction of shared citizenship.

These unresolved tensions cast some doubts on the potential of agonistic populism to become a paradigm for the articulation of the urban space as a counterhegemonic force against the perverse influence of national interest regarding foreign duties.

In contrast, the view here presented defends that questions of scale and space are relevant for their political potential to create conflict between institutional levels and consequently to expose the blindspots in the hegemonic national view - in our case, the systematic negligence regarding cosmopolitan responsibilities. Therefore, the reason for reclaiming the megalopolitical space is not to substitute or replicate hegemonic discourses but to challenge them. What we vindicate is a distinctive political experience that has the potential to contrast with and challenge the domestic bias in the political deliberation at the national level. Additionally, by asserting the intrinsic and irreducible value of this local political space, we also justify its functional and 
instrumental value in the legitimation of the national and European polity regarding the fulfillment of international duties.

\subsection{Localized Cosmopoleis}

There is another way in which scale matters. When adapting cosmopolitan norms to the context of the local, we are recreating them in the conditions of civic realization, and these conditions tend to differ in tone and substance from their abstract formulation at the national level. Therefore, megalopolitics can also be defended as a case of democratic iterations, in the sense coined by Seyla Benhabib (2006) of progressive realization of the cosmopolis through the diffusion of universal principles in international norms by means of trans-national legal contagion (e.g., harmonization, adaptation, replication, accommodation). Benhabib illustrates the immanent dimension of this critical cosmopolitanism with a variety of cases in which this iusgenerative potential is realized through different jurisdictional levels of the EU (2004: 202-212). The distinctive take in our view shares the general conception of democratic iterations but makes explicit and substantiates the intrinsic ius-generative conditions of the urban scale.

The consequence of the normative creativity of the urban is that it is confronted with the daily adaptation of the politics of the urban commons to the claims of anyone who qualifies as a resident or commoner. The category of resident is a more universalist category of membership than national citizenship. It captures in a more emphatic way that actors are embedded and incardinated in localized social networks. Hence, residency can be read as a local determination of the cosmopolitan condition. In this fundamental sense, we are all global residents, and ideally, this is a condition that all democratic states should recognize for all their nationals as a legitimate channel for expressing fundamental alienation from state policy. Global residency would be therefore a default status for those exercising a right of exit within the state by renouncing their national citizenship and opting for realizing their political dimension at the local level (Álvarez 2016). Similarly, as global residents, refugees qualify as involuntary victims of a dysfunctional state.

This alternative approach to the cosmopolitan dimension of urban politics also differs from the populist articulation of social demands in that the voices of the new residents are not diluted into an overarching populist discourse. In contrast, they remain differentiated as reminders of the situation of those who were left behind. This irreducibility is part of the corrective cosmopolitan input from urban areas. The refugee crisis may also be portrayed as an extreme form of a politics of presence because even if only the fortunate $1 \%$ of refugees are resourceful enough to aspire to some level of integration in Western societies, their presence is one of the few ways that the other $99 \%$ have to make an entry into our domestic agendas. In this sense, we can think of them as the most articulate and undiplomatic ambassadors of our foreign global neighbors. 
The cosmopolitan agential condition here is critical because it goes beyond the right of asylum understood as a right to have rights, as a universal protection of political membership. This brilliant Arendtian formulation, productively developed by Seyla Benhabib, is occasionally read in a minimalistic key that assimilates the right of asylum to some basic conditions of hospitality. In contrast, the interpretation that this chapter defends is in line with the cosmopolitan notion of default global residence after state collapse. In particular, it develops the fundamental meaning of the right to have rights as the reconstruction of "a place in the world which makes opinions significant and actions effective" (Arendt 1973: 296). It is also important to emphasize the second part of Arendt's formulation, where she specifies that this means having a place where one is judged according to one's words and deeds (Arendt 1973: 296-297), that is, according to one's contributions as an individual and not merely as a part of a collective in need of humanitarian protection and assistance. Consequently, the proper cosmopolitan response to valid claims for residence is not only to provide resources but also to transform the built environment that we share so that it translates the contributions and interactions of newcomers into meaningful actions. This more detailed reading developed by Benhabib (2013) differs from the political turn sponsored by Beitz in that Benhabib makes explicit the moral core of intersubjective recognition, while Beitz (2013) narrows the focus to the practice of exchanging claims for urgent concern. While Beitz discusses how long a minimal list of rights for decent self-governing societies should be, Benhabib focuses instead on the conditions that validate the claims of others to rights. The local scale is a privileged setting for situating the self in the ethical thickness of concrete others that always remain as neighboring strangers. In this sense, in the urban agora, we reconstruct each other as subjects of specific rights. This applies, for instance, to the claims over urban commons, of meaningful agency, of opportunities for self-sufficient economic activity, of transborder mobility, and of reunion and affiliation in hosting networks.

The need to protect refugees' capacity for agency is also highlighted in Fassin's anthropological observations (Fassin 2012, 2016) and in Brett and Collier's proposal (2017). However, what the latter describe as the conditions for autonomy should be understood not in the moral sense but as economic self-sufficiency. Both meanings are nevertheless connected in the sense that life in the camps in situations of total dependency - with life on hold for decades, in many cases - puts to the test the sense of dignity and self-respect. All this is aggravated by the need of the individuals trapped in these circumstances to portray themselves as a living image of ultimate victimhood and destitution in order to appeal to foreign donors.

While the capacity to realize significant choices encapsulates the paradigmatic liberal conception of individual autonomy, the image of the refugee as a collective captures the liberal notion of charitable dependency. Fassin (2016) reminded us that the fate of the refugees was marked by an international devaluation of their status, from right to favor. Brett and Collier (2017) go one step further by conditioning refuge to national interest. By granting labor permits and market licenses to refugees in cities, camps and factories, the authors want to make the case for selfsufficiency as an individual need while also minimizing the cost of the correlative 
international responsibility. Although this second, pragmatic argument is questionable, the first defense of the right to economic activity converges with the right to be given proper consideration as an independent public persona and with the role that Ash Amin (2012: 35-58) confers to co-working as a source of social trust in the megalopolis.

A related consequence of the respect for the agential dimension of refugees is that hosting cities should facilitate the creation of social networks of support and interdependency through which the new residents may become significant participants and contributors. The capacity to reconstruct basic social fabric depends on associative efforts and the consolidation of a critical mass of potential interlocutors. It depends on shared social capital, linguistic skills for translation and personal communication, microeconomics of scale for sharing expenses, etc. These networks of support are the cumulative product of shared learning experiences and the mobilization of individuals searching for the optimal match. These networks often connect several cities through informal flows between communities, and they may even cross national borders. These transnational networks constitute part of the infrastructure of our urban era, and they are also of vital importance to determine how newcomers find a significant place and voice in the urban agora. The case of the European refugee flow is therefore an example of a transnational dynamic, generated by the complementary capacities of urban actors, which exceeds the national mind frame of the territorial state. Allowing refugees a sufficient degree of agency in the co-determination of their residence constitutes a challenge for the traditional attribute of state sovereignty of the capacity to control flows through the territory and is therefore an emerging point for friction and compromise. It is also an important realization of what the European project is. As we have argued so far, we cannot understand the city in isolation from its networks of flows and infrastructures. The European political project is also a metapolis of extended urban fabric that goes beyond national borders (Ascher 1995, 2009). This means that we need to understand ourselves as constituted by these flows of transnational communication that are an integral constituent of our shared political ideal.

\subsection{Conclusions}

From right, to favor, to empty promise. The tragedy of the refugee crises is a telling illustration that shows the unreliability of democratic societies to abide by their cosmopolitan duties and foreign commitments when they are insulated from electoral sanction and serious accountability (Christiano 2008, 2010, 2011, 2017). The alternatives may be to deflate the normative horizon so that it captures the realistically utopian limits of the morality of states; to better align international moral goals with national interests; or to transcend the limitation of a state-centered order by embedding our normative goals in global agencies with an explicit moral mandate (Lafont 2012, 2015, 2016).

Our examination of the refugee crises illustrates the difficulties of Christiano's conception of state consent and of Lafont's global regime of human rights to over- 
come this structural limitation. This chapter argues that the emergent global cities are non-national polities with the capacity to influence political deliberations in a more cosmopolitan direction. This is so because our megalopoleis are sites that realize a differentiated cosmopolitan ethos and because the human flows that connect them are also constitutive realities of a deeply interdependent political order (metapolis). The mismatch between national and metropolitan interests in the European Union is a case in point that needs to be given a political voice.

Finally, although agonistic populism constitutes an influential conception for the articulation of social demands, it does not provide an alternative to the domestic bias implicit in the idea of national interest. We argued that urban politics may become potential sites for contesting this national bias. However, agonistic populism lacks the political resources for the expression of such a counter-hegemonic force because it tends to override the specificities of the scale of the local agora in favor of an overarching conception of the people. In contrast, this chapter defends a cosmopolitan approach in the line of Benhabib's conception of democratic iteration. It argues that questions of scale are intrinsically ius-generative and that our megalopoleis should reflect this feature by incorporating refugees and emphasizing our common condition of residents in the cosmopoleis of Europe.

\section{References}

Álvarez, D. 2012. Individual Membership in a Global Order: Terms of Respect and Standards of Justification. Public Reason 4 (2): 92-118.

- 2016. Democracy for Idiots. Republicanism, Self-Alienation and Permanent Minorities. Revista Portuguesa de Filosofia 72 (4): 953-974. https://doi.org/10.17990/ RPF/2016_72_4_0953.

-2017. Democratic Legitimacy, International Institutions and Cosmopolitan Disaggregation. Law, Ethics \& Politics 4: 187-199.

Amin, A. 2012. Land of Strangers. Cambridge: Polity Press.

Amin, A., and N. Thrift. 2017. Seeing like a City. Cambridge: Polity Press.

Appaduray, A. 2004. The Capacity to Aspire: Culture and the Terms of Recognition. In Culture and Public Action, ed. V. Rao and M. Walton, 59-84. Redwood: Stanford University Press.

Arendt, H. 1973 [1948]. The Origins of Totalitarianism. New York: Harvest Books.

Ascher, F. 1995. Métapolis. Ou, l'avenir des villes. Paris: Éditions Odile Jacob. . 2009. L'âge des métapoles. La Tour-d'Aigues: Éditions l'Aube.

Beitz, C. 2009. The Idea of Human Rights. Oxford: Oxford University Press. 2013. From Practice to Theory. Constellations 20 (1): 27-37.

Benhabib, S. 2004. The Rights of Others: Aliens, Residents, and Citizens. Cambridge: Cambridge University Press.

- 2006. Another Cosmopolitanism. Oxford: Oxford University Press.

. 2013. Reason-Giving and Rights-Bearing: Constructing the Subject of Rights. Constellations 20 (1): 38-50.

Betts, A. 2015. The Normative Terrain of the Global Refugee System. Ethics \& International Affairs 29: 363-375.

Betts, A., and P. Collier. 2017. Refuge. Transforming a Broken Refugee System. London: Allen Lane.

Blake, M. 2016. Philosophy and the Refugee Crisis. What are the hard Questions? The Critique. [Especial issue -And Who is my Neighbor? Immigration, Human Rights and Sovereignty http:// www.thecritique.com/articles/philosophy-the-refugee-crisis-what-are-the-hard-questions/. 
Brenner, N. 2013. Theses on Urbanization. Public Culture 25 (1): 85-114.

Brenner, N., and C. Schmid. 2015. Towards a New Epistemology of the Urban? City 19 (2-3): $151-182$.

Carens, J.H. 2013. The Ethics of Immigration. Oxford: Oxford University Press.

Christiano, T. 2008. The Constitution of Equality. Democratic Authority and its Limits. Oxford: Oxford University Press.

- 2010. Democratic Legitimacy and International Institutions. In The Philosophy of International Law, ed. S. Besson and J. Tasioulas, 119-137. Oxford: Oxford University Press.

- 2011. An Instrumental Argument for a Human Right to Democracy. Philosophy \& Public Affairs 39: 142-176.

. 2017. Replies to David Álvarez, David Lefkowitz, and Michael Blake. Law, Ethics \& Politics 4: 221-236.

Fainstein, S. 2010. The Just City. Ithaca: Cornell University Press.

Fassin, D. 2012. Humanitarian Reason. A Moral History of the Present. Berkeley: University of California Press.

- 2016. From Right to Favor. The refugee Question as Moral Crisis. The Nation. https:// www.thenation.com/article/from-right-to-favor/.

Gibney, M. 2016. Liberal Democratic States and the Problem of the Refugee. Why Do Liebral

Democratic States maintain a Commitment to the Institution of Asylum? The Critique.

[Especial issue -And Who is my Neighbor? Immigration, Human Rights and Sovereignty http:// www.thecritique.com/articles/liberal-democratic-states-the-problem-of-the-refugee-2/.

Harvey, D. 2013. Rebel Cities. From the Right to the City to the Urban Revolution. London: Verso. Laclau, E. 2005. On Populist Reason. London: Verso.

Lafont, C. 2012. Global Governance and Human Rights, Spinoza Lectures Series. Amsterdam: Van Gorkum.

- 2015. Human Rights, Sovereignty and the Responsibility to Protect. Constellations 22 (1): $68-78$.

- 2016. Sovereignty and the International Protection of Human Rights. Journal of Political

Philosophy 24 (4): 427-445.

Lefebvre, H. 2003. The Urban Revolution. Minneapolis: University of Minnesota Press. . 2012. O Direito à Cidade. Lisbom: Estúdio e Letra Livre.

Miller, D. 2016. Strangers in Our Midst. The Political Philosophy of Immigration. Cambridge: Harvard University Press.

Mouffe, C. 2013. Agonistics: Thinking the World Politically. London: Verso.

. 2017. Radical Politics as Counter-Hegemonic Intervention: The Role of Cultural Practices.

In Ethics of the Urban. The City and the Spaces of the Political, ed. M. Mostafavi, 209-212. Zürich: Lars Muller Publishers.

Mouffe, C., and M. Miesse. 2012. The Space of Agonism. In The Space of Agonism. Markus Miessen in Conversation with Chantal Mouffe, ed. N. Hirsch and M. Miessen. Berlin: Stenberg Press.

Nicholls, W.J. 2008. The Urban Question Revisited: The Importance of Cities for Social Movements. International Journal of Urban and Regional Research 32 (4): 841-859.

Papanastasiou, N. 2017. How Does Scale Mean? A Critical Approach to Scale in the Study of Policy. Critical Policy Studies 11 (1): 39-56.

Purcell, M. 2009. Hegemony and Difference in Political Movements: Articulating Networks of Equivalence. New Political Science 31 (3): 291-317.

. 2013. Possible Worlds: Henri Lefebvre and the Right to the City. Journal of Urban Affairs 36 (1): 141-154.

Rawls, J. 1999. The Law of Peoples. Cambridge: Harvard University Press.

Raz, J. 1988. The Morality of Freedom. Oxford: Oxford University Press. 2010. Between Authority and Interpretation: On the Theory of law and Practical Reason.

Oxford: Oxford University Press.

Sandercock, L. 2003. Cosmopolis II. In Mongrel Cities in the 2st Century. London: Continuum. 
Sassen, S. 2005. Cityness in the Urban Agen. Urban Age Bulletin 4: 1-3.

. 2006. Territory, Authority, Rights. From Medieval to Global Assemblages. Princeton: Princeton University Press.

- 2013. Does the City have Speech? Public Culture 25 (2-70): 209-221.

2014. Expulsions. Brutality and Complexity in the Global Economy. Cambridge: Harvard University Press.

Soja, E.W. 2010. Seeking Spatial Justice. Minneapolis: University of Minnesota Press. 